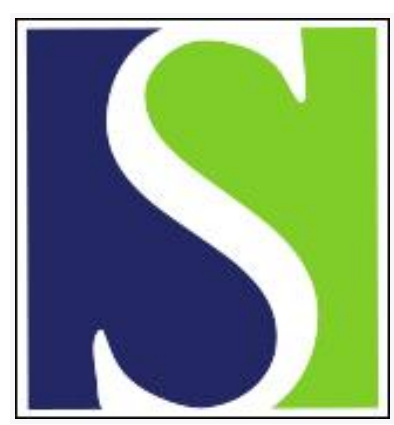

Scand J Work Environ Health 1988;14(6):385-389

https://doi.org/10.5271/sjweh.1905

Issue date: Dec 1988

Relation between lead and cadmium in blood and the involuntary smoking of children.

by Willers S, Schutz A, Attewell R, Skerfving S

Affiliation: Department of Occupational and Environmental Medicine, Lund University, General Hospital, Malmo, Sweden.

This article in PubMed: www.ncbi.nlm.nih.gov/pubmed/3212414

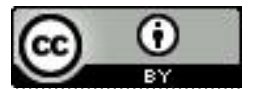




\title{
Relation between lead and cadmium in blood and the involuntary smoking of children
}

\author{
by Stefan Willers, MD, ${ }^{1}$ Andrejs Schütz, $\mathrm{PhD},{ }^{2}$ Robyn Attewell, MSc, ${ }^{2}$ Staffan Skerfving, $\mathrm{MD}^{2}$
}

\begin{abstract}
WILLERS S, SCHÜTZ A, ATTEWELL R, SKERFVING S. Relation between lead and cadmium in blood and the involuntary smoking of children. Scand J Work Environ Health 14 (1988) 385-389. The blood lead $(\mathrm{PbB})$ and blood cadmium $(\mathrm{CdB})$ levels, as well as the parental smoking habits, of 133 children aged 4 to 11 years were studied. The children were from a town with a lead smeltery and a surrounding rural area. There was a significant association between the higher $\mathrm{PbB}$ levels of the children and involuntary (parental) smoking in the home. The $\mathrm{CdB}$ levels of the children were not affected by parental smoking habits. The children whose parents did not smoke at home had lower $\mathrm{PbB}$ values than those with one smoking parent. These children, in turn, had lower levels than children with two smoking parents. Mothers who smoked had a greater impact than fathers who smoked. There was also a dose-response relationship between the amount of tobacco smoked by the mother and the $\mathrm{PbB}$ level of the child. The PbB value was higher for the children living near industrial lead emissions than for children from the rural area. The association between $\mathrm{PbB}$ level and involuntary smoking is probably not due to inhalation of lead originating from tobacco smoke. A small airways disease affecting the absorption of inhaled lead particles is proposed as an explanation.
\end{abstract}

Key terms: emission, environmental, passive, pollution, smoke, tobacco, traffic.

Well-known factors associated with an elevated blood lead $(\mathrm{PbB})$ level in children are industrial lead emissions, automobile exhaust, peeling lead paint, lead pipes in drinking water systems, lead-exposing hobbies, lead-exposing occupations of parents, lead-soldered cans, and lead-glazed earthenware $(2,3,4,19$, 21).

In an earlier study of environmental exposure to lead and arsenic among children between the ages of 8 and 11 years and living near a glassworks in a rural area, we found that parental smoking habits had a considerable effect on $\mathrm{PbB}$ and urinary arsenic levels (1). Children of parents who smoked had higher levels than children of nonsmoking parents. In addition there was a relationship between the $\mathrm{PbB}$ level and the number of smokers in the household, and for children with one smoking parent the effect of the mother's smoking was larger than that of the father's.

It is well known that tobacco contains heavy metals such as lead, cadmium, and arsenic $(13,15,25)$. Moreover, in active smokers, the mean $\mathrm{PbB}$ level is higher than in nonsmokers $(6,7,8,18,23)$. However, the relative incremental effect of the cadmium concentration in the blood of smokers is far greater than that of the $\mathrm{PbB}$ concentration $(6,8,10,23,26)$.

\footnotetext{
1 Department of Occupational and Environmental Medicine, Lund University, General Hospital, Malmö, Sweden.

2 Department of Occupational and Environmental Medicine, University Hospital, Lund, Sweden.
}

Reprint requests to: Dr S Willers, Department of Occupational and Environmental Medicine, Lund University, General Hospital, S-214 01 Malmö, Sweden.
In the present study, we have further investigated the effect of involuntary smoking upon $\mathrm{PbB}$ and blood cadmium $(\mathrm{CdB})$ levels.

\section{Subjects and methods}

\section{Subjects}

In the beginning of June 1986 venous blood samples were obtained from children living in the town of Landskrona or the surrounding rural district. In five kindergartens in Landskrona, 75 out of 79 children four to six years of age agreed to participate. For six children the blood sampling was unsuccessful. Another group $(\mathrm{N}=64)$ was sampled at random from a larger group of children (aged 8-11 years) from two schools in Landskrona and one school in the rural district. Thus a total of 133 children were studied. Sixty-six were boys, and 67 were girls.

\section{Lead and cadmium exposure}

Since 1944, Landskrona has housed a secondary lead smeltery, mainly handling automobile batteries. In late 1984, close to the first smeltery, another lead emitting smeltery, which processes metal dusts from ferrous smelteries located elsewhere, was built. The other major source of lead emission in Landskrona is automobile exhaust. The lead levels of vegetables have been measured yearly since 1981 , and they were somewhat higher in Landskrona than in other Swedish towns.

The location of the children's homes was classified into three groups, ie, within $1 \mathrm{~km}$ of the smelteries, 
in other urban areas, and in rural areas (ie, outside the town of Landskrona).

There is no major industrial emission of cadmium in Landskrona.

\section{Interview}

One parent of each child was questioned on the telephone by an interviewer not knowing the results of the metal analyses. The interviewer asked about hobbies with potential lead exposure (yes/no), lead-exposing parental occupations (yes/no), and the child's weekly intake of canned foods (yes/no). The parent was also asked about the traffic situation around the home (light/heavy). Heavy traffic was defined as a main road just outside the home (within $10 \mathrm{~m}$ ). Furthermore, the parent was asked about both parents' smoking habits. These were scored in four groups as follows: $0=$ never smoker or ex-smoker who had stopped smoking more than 0.5 years ago; $1=$ smoker of one to seven cigarettes a day or ex-smoker who had stopped smoking less than 0.5 years ago; $2=$ smoker of 8 to 15 cigarettes daily; and $3=$ smoker of more than 15 cigarettes daily ( $1 \mathrm{~g}$ of pipe tobacco was approximated to equal one cigarette). The smokers were asked if they smoked indoors at home (yes/no).

The project was approved by the Ethics Committee of the Lund University. Informed written consent was obtained from both the children and their parents.

\section{Lead analyses}

The blood samples were wet-ashed with nitric acid, whereafter lead was complexed with dithizone, extracted, and determined by flame atomic absorption spectrometry (22). The detection limit was $10 \mu \mathrm{g} / \mathrm{l}(0.05$ $\mu \mathrm{mol} / \mathrm{l})$.

All samples were analyzed in one campaign. Each analytical series contained six samples from both areas, two blanks containing reagents only and four containing "normal" blood samples, two of which were spiked with a known amount of lead. The coefficient of variation, as calculated from duplicate analyses, of different series (of 80 of the present samples) was $5.3 \%$ of the mean $(42 \mu \mathrm{g} / 1$ or $0.20 \mu \mathrm{mol} / \mathrm{l})$.

The accuracy has been tested twice each year in an inter-Nordic laboratory calibration program with 14 to 20 laboratories participating on each occasion. At a $\mathrm{PbB}$ of $80 \mu \mathrm{g} / \mathrm{l}(0.39 \mu \mathrm{mol} / \mathrm{l})$ or less, our results for 23 samples averaged 94 (range $84-103$ ) $\%$ of the mean. Furthermore we participated in the United Kingdom External Quality Assessment Scheme. In the nine quality control samples analyzed during the period of analysis of the samples in the present study, our results averaged $99 \%$ (range $91-107 \mu \mathrm{g} / 1$ or $0.44-0.52$ $\mu \mathrm{mol} / \mathrm{l}$ ) of about 80 participating laboratories.

\section{Cadmium analyses}

In $0.5-\mathrm{ml}$ blood samples the proteins were precipitated by the addition of $0.5 \mathrm{ml}$ of deionized water and
$0.5 \mathrm{ml}$ of ultrapure nitric acid (Merck, Federal Republic of Germany). The samples were centrifuged and analyzed by electrothermal atomic absorption spectrometry (6). An autosampler and a deuterium background corrector were employed. Each series of nine blood samples included three reagent blanks. The technique of standard addition was used and included the addition of two different concentrations to each sample. Two atomizations of each sample were made. The detection limit was $0.05 \mu \mathrm{g} / 1(0.45 \mathrm{nmol} / \mathrm{l})$. The precision was $18 \%$ (coefficient of variation), as calculated from duplicate analyses of 30 samples (mean 0.17 $\mu \mathrm{g} / 1$ or $1.51 \mathrm{nmol} / 1)$, and $15 \%$, as calculated from 11 analyses of a standard blood sample on different days (mean $0.14 \mu \mathrm{g} / \mathrm{l}$ or $1.25 \mathrm{nmol} / \mathrm{l}$ ). The accuracy was checked from a lyophilized reference sample (Seronorm TM Trace Elements, Batch No 901, Nycomed AS, Oslo, Norway) included in the sample series on different days. The reference samples were diluted 10 times before the analyses. Our results averaged 0.78 (SD 0.03) $\mu \mathrm{g} / \mathrm{l}$ [ie, 6.94 (SD 0.267) nmol/l], whereas the "preliminary recommended value" was 0.74 (7.4 undiluted) $\mu \mathrm{g} / \mathrm{l}$ [ie, $6.584(65.84$ undiluted) $\mathrm{nmol} / \mathrm{l}$ ] . Furthermore, for 12 samples in an international quality control scheme, our results averaged 107 (range $89-130) \%$ of the certified values [mean $1.88 \mu \mathrm{g} / 1$ $(16.73 \mathrm{nmol} / \mathrm{l})$, range $0.40-3.15 \mu \mathrm{g} / \mathrm{l}(3.56-28.03$ $\mathrm{nmol} / \mathrm{l})]$.

\section{Statistics}

The $\mathrm{PbB}$ and $\mathrm{CdB}$ levels had skewed distributions, and logarithmic transformation was therefore employed. The geometric means and standard deviations $[\exp (\mathrm{SD}$ $\log \mathrm{x})]$ have been quoted as descriptive statistics. An analysis of variance was used, with simultaneous adjustment for age, sex, parental smoking habits, area of residence, and traffic intensity in area of residence.

\section{Results}

\section{Blood lead levels}

For the total unadjusted material, the geometric mean of the $\mathrm{PbB}$ concentration was $40.2 \mu \mathrm{g} / \mathrm{l}(0.19 \mu \mathrm{mol} / \mathrm{l})$ (table 1). There was a significant increase in the $\mathrm{PbB}$ level according to the number of parents who smoked $(P=0.004$, test for trend). The effect was even stronger for the number of parents who actually smoked at home $(\mathrm{P}<0.001)$. For children with neither parent smoking at home, the mean $\mathrm{PbB}$ level was $34.5 \mu \mathrm{g} / \mathrm{l}$ $(0.17 \mu \mathrm{mol} / \mathrm{l})$. This value included 38 children whose parents never smoked (mean $35.3 \mu \mathrm{g} / 1$ or $0.17 \mu \mathrm{mol} / \mathrm{l}$ ) and 13 children whose parents only smoked outside their homes (mean $32.1 \mu \mathrm{g} / \mathrm{l}$ or $0.16 \mu \mathrm{mol} / \mathrm{l}$ ). For children with one smoking parent, the mean was $42.4 \mu \mathrm{g} / \mathrm{l}$ $(0.21 \mu \mathrm{mol} / \mathrm{l})$, and for those with two smoking parents it was $47.2 \mu \mathrm{g} / 1(0.23 \mu \mathrm{mol} / \mathrm{l})$. For children with a father who smoked and a nonsmoking mother, the level was $39.8 \mu \mathrm{g} / \mathrm{l}$, and for those with a mother who 
Table 1. Unadjusted geometric means, geometric standard deviations (GSD), and range of the lead concentration in blood (PbB) and the cadmium concentration in blood (CdB) for 133 children in relation to their sex, their parental smoking habits, industrial lead emissions (living area), and traffic situation in their area of residence.

\begin{tabular}{|c|c|c|c|c|c|c|c|c|}
\hline & \multicolumn{4}{|c|}{$\mathrm{PbB}\left(\mu \mathrm{g} / \mathrm{l}^{\mathrm{a}}\right)$} & \multicolumn{4}{|c|}{$\mathrm{CdB}\left(\mu \mathrm{g} / /^{\mathrm{b}}\right)$} \\
\hline & $\begin{array}{c}\text { Number } \\
\text { of children }\end{array}$ & $\begin{array}{c}\text { Geometric } \\
\text { mean }\end{array}$ & GSD & Range & $\begin{array}{c}\text { Number } \\
\text { of children }\end{array}$ & $\begin{array}{l}\text { Geometric } \\
\text { mean }\end{array}$ & GSD & Range \\
\hline Total & 133 & 40.2 & 1.4 & $14-84$ & $105^{c}$ & 0.14 & 1.7 & $0.05-0.61$ \\
\hline \multicolumn{9}{|l|}{ Sex } \\
\hline $\begin{array}{l}\text { Boys } \\
\text { Girls }\end{array}$ & $\begin{array}{l}66 \\
67\end{array}$ & $\begin{array}{l}40.7 \\
39.8\end{array}$ & $\begin{array}{l}1.4 \\
1.4\end{array}$ & $\begin{array}{l}22-84 \\
14-80\end{array}$ & $\begin{array}{l}55 \\
50\end{array}$ & $\begin{array}{l}0.13 \\
0.14\end{array}$ & $\begin{array}{l}1.8 \\
1.6\end{array}$ & $\begin{array}{l}0.05-0.42 \\
0.06-0.61\end{array}$ \\
\hline \multicolumn{9}{|l|}{ Smoking } \\
\hline \multicolumn{9}{|l|}{ Parental smoking } \\
\hline $\begin{array}{l}\text { None } \\
\text { One }\end{array}$ & $\begin{array}{l}38 \\
54\end{array}$ & $\begin{array}{l}35.2 \\
41.3\end{array}$ & $\begin{array}{l}1.4 \\
1.3\end{array}$ & $\begin{array}{l}14-84 \\
24-80\end{array}$ & $\begin{array}{l}30 \\
42\end{array}$ & $\begin{array}{l}0.13 \\
0.14\end{array}$ & $\begin{array}{l}1.6 \\
1.7\end{array}$ & $\begin{array}{l}0.06-0.32 \\
0.05-0.61\end{array}$ \\
\hline $\begin{array}{l}\text { Father } \\
\text { Mother }\end{array}$ & $\begin{array}{l}17 \\
37\end{array}$ & $\begin{array}{l}38.5 \\
43.0\end{array}$ & $\begin{array}{l}1.3 \\
1.3\end{array}$ & $\begin{array}{l}24-73 \\
26-80\end{array}$ & $\begin{array}{l}13 \\
29\end{array}$ & $\begin{array}{l}0.11 \\
0.16\end{array}$ & $\begin{array}{l}1.5 \\
1.8\end{array}$ & $\begin{array}{l}0.05-0.22 \\
0.06-0.61\end{array}$ \\
\hline Both & 41 & 43.4 & 1.5 & $21-80$ & 33 & 0.14 & 1.8 & $0.05-0.40$ \\
\hline \multicolumn{9}{|l|}{ At home } \\
\hline None & 51 & 34.5 & 1.4 & $14-84$ & 37 & 0.13 & 1.6 & $0.06-0.34$ \\
\hline $\begin{array}{l}\text { Nonsmokers } \\
\text { Smokers }\end{array}$ & $\begin{array}{l}38 \\
13\end{array}$ & $\begin{array}{l}35.3 \\
32.1\end{array}$ & $\begin{array}{l}1.4 \\
1.3\end{array}$ & $\begin{array}{l}14-84 \\
22-43\end{array}$ & $\begin{array}{r}30 \\
7\end{array}$ & $\begin{array}{l}0.13 \\
0.13\end{array}$ & $\begin{array}{l}1.6 \\
1.6\end{array}$ & $\begin{array}{l}0.06-0.32 \\
0.08-0.34\end{array}$ \\
\hline One & 49 & 42.4 & 1.3 & $24-80$ & 41 & 0.14 & 1.6 & $0.05-0.61$ \\
\hline $\begin{array}{l}\text { Father } \\
\text { Mother }\end{array}$ & $\begin{array}{l}14 \\
35\end{array}$ & $\begin{array}{l}39.8 \\
43.4\end{array}$ & $\begin{array}{l}1.3 \\
1.3\end{array}$ & $\begin{array}{l}24-73 \\
26-80\end{array}$ & $\begin{array}{l}12 \\
29\end{array}$ & $\begin{array}{l}0.11 \\
0.16\end{array}$ & $\begin{array}{l}1.5 \\
1.8\end{array}$ & $\begin{array}{l}0.05-0.22 \\
0.06-0.61\end{array}$ \\
\hline Both & 33 & 47.2 & 1.4 & $21-80$ & 27 & 0.14 & 1.8 & $0.05-0.40$ \\
\hline \multicolumn{9}{|c|}{ Cigarettes smoked per day by mother } \\
\hline $\begin{array}{l}0 \\
1-7 \\
8-15 \\
>15\end{array}$ & $\begin{array}{l}55 \\
21 \\
24 \\
33\end{array}$ & $\begin{array}{l}35.2 \\
41.7 \\
41.7 \\
45.6\end{array}$ & $\begin{array}{l}1.4 \\
1.4 \\
1.4 \\
1.4\end{array}$ & $\begin{array}{l}14-84 \\
27-80 \\
22-68 \\
21-78\end{array}$ & $\begin{array}{l}43 \\
19 \\
17 \\
26\end{array}$ & $\begin{array}{l}0.12 \\
0.15 \\
0.15 \\
0.14\end{array}$ & $\begin{array}{l}1.6 \\
1.7 \\
1.8 \\
1.8\end{array}$ & $\begin{array}{l}0.05-0.32 \\
0.05-0.36 \\
0.06-0.42 \\
0.06-0.61\end{array}$ \\
\hline \multicolumn{9}{|l|}{ Area of residence } \\
\hline $\begin{array}{l}\text { Near smeltery } \\
\text { (within } 1 \mathrm{~km} \text { ) } \\
\text { Urban } \\
\text { Rural }\end{array}$ & $\begin{array}{l}14 \\
67 \\
52\end{array}$ & $\begin{array}{l}45.9 \\
43.2 \\
35.4\end{array}$ & $\begin{array}{l}1.4 \\
1.4 \\
1.4\end{array}$ & $\begin{array}{l}24-78 \\
20-84 \\
14-73\end{array}$ & $\begin{array}{l}13 \\
53 \\
39\end{array}$ & $\begin{array}{l}0.16 \\
0.13 \\
0.14\end{array}$ & $\begin{array}{l}1.6 \\
1.8 \\
1.6\end{array}$ & $\begin{array}{l}0.09-0.42 \\
0.05-0.61 \\
0.06-0.34\end{array}$ \\
\hline \multicolumn{9}{|c|}{ Traffic in area of residence } \\
\hline $\begin{array}{l}\text { Light } \\
\text { Heavy }\end{array}$ & $\begin{array}{r}103 \\
30 \\
\end{array}$ & $\begin{array}{l}39.3 \\
42.3 \\
\end{array}$ & $\begin{array}{l}1.4 \\
1.4 \\
\end{array}$ & $\begin{array}{l}14-80 \\
21-84 \\
\end{array}$ & $\begin{array}{l}79 \\
26 \\
\end{array}$ & $\begin{array}{l}0.13 \\
0.15 \\
\end{array}$ & $\begin{array}{l}1.7 \\
1.7 \\
\end{array}$ & $\begin{array}{l}0.05-0.61 \\
0.06-0.42 \\
\end{array}$ \\
\hline
\end{tabular}

a $1 \mu \mathrm{g} / \mathrm{l}=0.004826 \mu \mathrm{mol} / \mathrm{l}$.

b $1 \mu \mathrm{g} / \mathrm{l}=8.897 \mathrm{nmol} / \mathrm{l}$.

c For 28 children the blood samples were too small to permit cadmium analysis.

smoked and a nonsmoking father, it was $43.4 \mu \mathrm{g} / 1$ $(0.19 \mu \mathrm{mol} / \mathrm{l})$. When the level of smoking by the parents was taken into account, a significant positive relationship was observed for the mother's cigarette consumption $(P=0.01)$ (table 1$)$ but not for the father's $(\mathrm{P}=0.2)$.

The $\mathrm{PbB}$ value also depended upon the location of the home. Those children living near the smelteries had the highest levels, other urban children had intermediate values, and those living in rural areas had the lowest values (table 1). The pattern was similar when the other factors were taken into account. Statistically significant differences were observed between the three regions when the number of parents who smoked was included in the model $(P=0.02)$. However, when this factor was replaced by the number of parents smoking at home, only the difference between the two urban regions and the rural area remained statistically significant $(\mathrm{P}=0.05)$.
There was no significant effect of the heaviness of traffic in the area of residence (table 1).

\section{Blood cadmium levels}

In the total group, the geometric mean of the CdB concentration was $0.14 \mu \mathrm{g} / 1(1.25 \mathrm{nmol} / \mathrm{l})$ (range $0.05-$ $0.61 \mu \mathrm{g} / 1$ or $0.45-5.43 \mathrm{nmol} / \mathrm{l})$. There were no significant differences with respect to age, sex, parental smoking habits, area of residence, or traffic intensity in the area of residence (table 1). There was no significant correlation between the $\mathrm{PbB}$ and $\mathrm{CdB}$ values.

\section{Discussion}

The PbB levels measured in our study are low when compared with those of many other countries $(2,3$, 9), but they are similar to levels in other areas of Sweden $(1,10,22)$. 
There was an association between the PbB levels of the children and parental smoking, and this finding is in accordance with the results of our earlier report (1). It is also in agreement with scattered earlier observations. Sherlock et al (19) showed, in 1985, that children with one or more parents who smoked tended to have a higher $\mathrm{PbB}$ value than children with nonsmoking parents, although the difference was not statistically significant. Furthermore, in a study of the association between traffic and $\mathrm{PbB}$, there were indications that passive smoking increased the uptake of ambient lead in children (4). It is interesting that the present absolute effect of passive smoking is similar to that reported for active smoking (in adults) $(6,8$, $18,23)$, the relative effect being even greater. We have no reason to believe that some of the children were deceivers (ie, active smokers) because of the low mean age of the study group.

Smoking habits of parents is, of course, a rough index of the smoke exposure of the child. It is interesting to note, however, that there was an association with the level of smoking among the mothers. We have no information about other factors which may have influenced the children's exposure, such as room volume and ventilation, places indoors where smoking has occurred, or proximity to the smoker. There is a need for an objective classification of involuntary tobacco smoke exposure. A dose-response relationship with passive exposure to tobacco smoke has earlier been shown for cotinine, the major metabolite of nicotine $(12,20)$. This finding may offer a possibility for further research.

The CdB levels of the children in our study were low when compared with those of children in the Federal Republic of Germany (2), but they are in agreement with determinations for other Swedish children (10). The levels of the children in our study were lower than those of nonsmoking Swedish teachers $(0.5 \mu \mathrm{g} / 1$ or 4.45 nmol/l) (8), who, in turn, had lower levels than teachers from other countries $(8,26)$. In spite of the much larger impact of active smoking upon $\mathrm{CdB}$ than on $\operatorname{PbB}(6,8,23,26)$, the $\mathrm{CdB}$ values of our children were not associated with parental smoking habits. This finding is in accordance with observations by Watanabe et al (26), who studied adult passive smokers (farmers).

The inhalation of particles containing lead from tobacco smoke could be an explanation of the effect on the PbB level. However, cigarettes contain almost as much cadmium as lead $(13,25)$. A similar effect of involuntary smoking on $\mathrm{CdB}$ should thus be expected. Furthermore the majority of the cadmium in a cigarette is released in the sidestream smoke (16), and it is thus available for passive smoking. Only $22-50 \%$ of the cadmium has been found in the ashes and stumps of cigarettes (15). The lead content of sidestream smoke is not known. However, almost all lead has been found to remain in the remnants of the smoked cigarette (15). Thus the lead content of the en- vironmental tobacco smoke is a less likely explanation of the increased $\mathrm{PbB}$ of involuntary smokers. A rough calculation shows that the amount of lead inhaled through involuntary smoking is small when compared to that of background exposure, mainly from water, food, and air.

Thus other possible explanations must be considered. Involuntary smoking might be associated with other lead exposures, eg, a general contamination of the home with tobacco ash. Another possible explanation is an association between parental smoking and family life-style factors, eg, poorer hygiene (ie, handwashing habits, dustier homes) and/or differences in food habits between families with smokers and nonsmokers. Furthermore smoking alters the metabolism of different drugs (14). Thus the distribution and/or elimination of lead may possibly be affected in passive smokers.

There are, however, other possibilities. It is well known that children exposed to tobacco smoke suffer from bronchitis and pneumonia more frequently than children of nonsmokers (17). Moreover, tobacco smoke can inactivate alveolar macrophage tissue transglutaminase, which may, hypothetically, decrease the phagocytosis of lead particles in the alveoli (Stenberg, personal communication). Smokers have an impaired dust clearance from the lung $(5,27)$. A less efficient pulmonary clearance in the children of smokers may thus cause an increased retention of particles in the alveoli. In addition the damage of the mucosa by the tobacco smoke exposure increases the permeability of the airway epithelium (11), and this increase may result in an increased absorption of lead from environmental air due to traffic or other sources.

Because of the low background $\mathrm{PbB}$ level and the relationship between exposure and $\mathrm{PbB}$ at this level (3), even a small increase in exposure may produce a noticeable increase in the $\mathrm{PbB}$ value. Due to a lower impact of exposure on $\mathrm{PbB}$ at higher exposure levels, the same increase in exposure would not cause such a noticeable increase in $\mathrm{PbB}$. The effect of involuntary smoking on $\mathrm{PbB}$ might, therefore, be undetectable in groups with a higher background exposure.

We found that the effect of the mother's smoking on $\mathrm{PbB}$ was particularly great. This phenomenon may be due to the fact that mothers smoke closer to their children than fathers do. Alternatively, maternal smoking during pregnancy may be of importance, as it has been shown to increase the risk for lower respiratory illness (24). The maternal smoking habits at the time of our study were probably associated with the smoking habits during pregnancy.

The lack of any association between involuntary smoking and $\mathrm{CdB}$ levels may indicate that the relative exposure to cadmium by inhalation (as compared to other routes) is lower than it is for lead. Thus, the impact of a small airways disease on $\mathrm{CdB}$ would be less.

If the higher $\mathrm{PbB}$ values of the children with parents who smoke are an indicator of small airways dis- 
ease, exposure to other irritant air pollutants, such as sulfur dioxides and nitrogen oxides, might also increase the PbB level. Therefore, in the present study, the smeltery, as well as other irritant-emitting industries in the area, may be, at least partially, the cause of the higher $\mathrm{PbB}$ levels in the area near the lead smeltery, and the differences may not be entirely due to lead emission levels. There was a gradient in the PbB level from the lead smeltery area outwards, even when adjustment was made for area differences in the prevalence of passive smoking. Earlier we found that the $\mathrm{PbB}$ levels of children had decreased during the last 10 years (22), the decrease averaging $7 \%$ per year. During this period, the prevalence of smoking had also decreased. However, the decrease in PbB cannot be explained by a decrease of passive smoking only. The main reason is probably a decrease in environmental lead pollution from traffic and industries.

The considerable effect of involuntary smoking of children and/or the fetus on the amount of lead absorbed may also act as a confounder of the reported associations between lead exposure and central nervous system effects (9). Thus effects claimed to be due to lead might, to some extent, be due to other factors associated with involuntary smoking.

\section{Acknowledgments}

This study was supported by a grant from the Swedish National Environment Protection Board.

Excellent assistance was given by Ms C Andersson and Mr A Ekholm.

\section{References}

1. Andre'n P, Schütz A, Vather M, Attewell R, Johansson L, Willers S, Skerfving S. Environmental exposure to lead and arsenic among children living near a glassworks. Sci Total Environ (in press).

2. Brockhaus A, Collet W, Dolgner R, Engelke R, Ewers U, Freier I, Jermann E, Krämer U, Manojlovic N, Turfeld M, Winneke G. Exposure to lead and cadmium of children living in different areas of North-West Germany. Int Arch Occup Environ Health 60 (1988) 211-222.

3. Brunekreef B. The relationship between air lead and blood lead in children: A critical review. Sci Total Environ 38 (1984) $79-123$.

4. Clench-Aas J, Thomasen Y, Levy F, Skoug K. Blood lead - A function of vehicular emissions and smoking: Part 1. Norwegian Institute for Air Research, Oslo 1984. (NILU, OR: 43/84, reference: 0-8302).

5. Cohen D, Arai S, Brain J. Smoking impairs long-term dust clearance from the lung. Science 204 (1979) 514517.

6. Elinder CG, Friberg L, Lind B, Jaawaid M. Lead and cadmium levels in blood samples from the general population of Sweden. Environ Res 30 (1983) 233-253.

7. Ernhart CB, Wolf AW, Sokol RJ, Brittenham GM, Erhard P. Fetal lead exposure: Antenatal factors. Environ Res 38 (1985) 54-66.

8. Friberg L, Vahter M. Assessment of exposure to lead and cadmium through biological monitoring: Results of a UNEP/WHO global study. Environ Res 30 (1983) 95-128.

9. Fulton M, Thomson G, Hunter R, Raab G, Laxen D,
Hepburn W. Influence of blood lead on the ability and attainment of children in Edinburgh. Lancet 1 (1987) $1221-1225$.

10. Granvik M, Sandberg BM, Friberg L, Lind B, Nilsson B. Lăga halter av bly och kadmium i blod hos skolbarn i Dalarna [Low levels of lead and cadmium in blood in schoolchildren in Dalarna, Sweden]. Läkartidningen 85 (1988) $320-322$.

11. Hulbert WC, Walker DC, Jackson A, Hogg JC. Airway permeability to horseradish peroxidase in guinea pigs: The repair phase after injury by cigarette smoke. Am Rev Respir Dis 123 (1981) 320-326.

12. Jarvis MJ, Russell MAH, Feyerabend C, Eiser JR, Morgan M, Gammage P, Gray EM. Passive exposure to tobacco smoke: Saliva cotinine concentrations in a representative population sample of non-smoking school children. Br Med J 2291 (1985) 927-929.

13. Jenkins RA. Occurrence of selected metals in cigarette tobaccos and smoke. IARC Sci Publ 71 (1986) 129-138.

14. Luczynska $C$, Wilson $K$. The clinical significance of the effects of cigarette smoking on drug disposition. Methods Find Exp Clin Pharmacol 5 (7) (1983) 497487.

15. Mussalo-Rauhmaa H, Salmela SS, Leppänen A, Pyysalo $\mathrm{H}$. Cigarettes as a source of trace and heavy metals and pesticides in man. Arch Environ Health 41 (1986) $49-54$.

16. Oberdörster G, Pott F. Extrapolation from rat studies with environmental tobacco smoke (ETS) to humans: Comparison of particle mass deposition and of clearance behaviour of ETS compounds. Toxicol Lett 35 (1986) $107-112$.

17. Pershagen G. Review of epidemiology in relation to passive smoking. Arch Toxicol 9 (1986) 63-73.

18. Shaper AG, Pocock SJ, Walker M, Wale CJ, Clayton B, Delves HT, Hinks L. Effects of alcohol and smoking on blood lead in middle-aged British men. Br Med J 284 (1982) 299-302.

19. Sherlock JC, Barltrop D, Evans WH, Quinn MJ, Smart GA, Strehlow C. Blood lead concentrations and lead intake in children of different ethnic origin. Hum Toxicol 4 (1985) 513-519.

20. Skarping G, Willers S, Dalene M. Determination of cotinine in urine using glass capillary GC and selective detection. By special reference to the biological monitoring of passive smoking. J Chromatogr (in press).

21. Skerfving S. Biological monitoring of exposure to inorganic lead. In: Clarkson TW, Friberg L, Nordberg GF, Sager PR, ed. Biological monitoring of toxic metals. Plenum Publishing Corporation, New York, NY 1988, pp 169-197.

22. Skerfving S, Schütz A, Ranstam J. Decreasing lead exposure in Swedish children, 1978-1984. Sci Total Environ 58 (1986) 225-229.

23. Svensson B-G, Björnham Å, Schütz A, Lettewall U, Nilsson A, Skerfving S. Acidic deposition and human exposure to toxic metals. Sci Total Environ $67(2-3)$ (1987) $101-115$.

24. Taylor B, Wadsworth J. Maternal smoking during pregnancy and lower respiratory tract illness in early life. Arch Dis Child 62 (1987) 786-791.

25. Watanabe T, Kasahara M, Nakatsuka H, Ikeda M. Cadmium and lead contents of cigarettes produced in various areas of the world. Sci Total Environ 66 (1987) 29-37.

26. Watanabe T, Koizumi A, Fujita H, Kumai M, Ikeda M. Cadmium levels in the blood of inhabitants in nonpolluted areas in Japan with special references to aging and smoking. Environ Res 31 (1983) 472-483.

27. Westergaard O, Olsen P. Smoking and airway movement in the upper respiratory tract. Arch Klin Exp Ohren- Nasen- Kehlkopheilkd 203 (1973) 179-183.

Received for publication: 3 October 1988 